\title{
Case Study of Implementation 2013 Curriculum in Elementary School Kauman 1 Malang, Indonesia
}

\author{
Raditya Eka Oktarina \\ Department of Educational Management \\ Universitas Negeri Malang, Indonesia \\ raditya.ookta@gmail.com
}

\author{
Rifqi Ilma Fararisti \\ Department of Educational Management \\ Universitas Negeri Malang, Indonesia \\ ilmarifqi@gmail.com
}

\author{
Mustiningsih \\ Department of Educational Administration \\ Universitas Negeri Malang, Indonesia \\ mustiningsih.fip@um.ac.id
}

\begin{abstract}
This study aims to compare the 2013 curriculum with KTSP as the previous curriculum at SDN Kauman 1 Malang and to examine the problems related to the implementation of 2013 curriculum implemented at the School. The method used in this study is a qualitative descriptive method with case study approach through interviews, observation and documentation. The result shows a clear difference between the two curricula. In addition, several problems related to the implementation of the 2013 curriculum were found, which were solved together with several related parties.
\end{abstract}

Keywords: comparison, curriculum, KTSP, elementary, implementation

\section{INTRODUCTION}

Education is one of the most important needs in life today. This is because education has become one of the things needed in the process of sustainable living. As [1] in his book explains that education is a process of cultural transmission from one generation to the next, emphasizing the mental aspects and rationality to prepare for future work, so that the creation of noble dignity. To maximize the benefits of education as part of our needs, this education must be based on a solid foundation.

This strong foundation can be reflected in the curriculum which is a part that governs the education's course. Curriculum is interpreted to mean all of the organized courses, activities, and experiences which pupils have under direction of the school, whether in the classroom or not [2]. The curriculum is defined as written material that contains a description of the education program of a school or madrasah that must be implemented from year to year [3]. Therefore, it is important to formulate a curriculum that suits the needs and current developments. The curriculum continues to development for the sake of these adjustments. At the moment the curriculum used is the 2013 curriculum.

The 2013 curriculum is a new curriculum that began to be applied in the 2013/2014 school year as the result of the development from the previous curriculum, which is the competency-based curriculum in 2004 and KTSP 2006. The existence of 2013 curriculum becomes a great attention and leads to controversy for most people, because some people regard 2013 curriculum is not ready to implement [4]. The government as an institution has the authority to regulate a number of policies for the good and regularity of citizens the country. The government has set policies, which is about education. Curriculum of 2013 is one of the government's effort to resolve the various problems being faced by the world of education today [5]. The curriculum as one of the policies determined by the minister of education. In the education's world, the curriculum holds a key position. Because it is related to determining the direction, content and educational process which ultimately determines how qualifications graduates of an educational institution. However, the implementation of 2013 curriculum will run well with the support of teacher or staff. The values of 2013 curriculum will be conveyed through them [6].

From the background explanation above, the researcher conducted a field case study in one of the leading schools in Malang, namely Primary School Kauman 01 Malang. The aims of this study are to discovery the problems related to the implementation of the 2013 curriculum implemented in schools. It will be related to the theory used so that solutions can be found from the problem. This study limits the scope of previous curriculum comparisons only by comparing the 2013 curriculum with the KTSP and only examines at the elementary school level.

\section{METHOD}

This type of research was descriptive qualitative with case study approach because it described the teacher's perception of implementation 2013 curriculum at one public elementary school located in Malang. The case study aims to improve the knowledge of the real contemporary communication events in its context [7]. This research was conducted in Primary School Kauman 01 Malang. The school was selected based on criteria that was familiar with the instruction and was pilot project school to implement the curriculum once it was firstly launched in 2013

The data was collected by doing observation, interview and document collection with the curriculum section in the school. The other data was collected by doing direct observation in Primary School Kauman 01 Malang. Observation is a method of data collection using observation of research object [8]. In this research, observations were conducted by college student in the Primary School Kauman 01. The instrument of observation used to collect data on the implementation 2013 curriculum of Primary School Kauman 01 Malang. formal interviews provided the teachers (curriculum 
section) with the opportunity to describe and explain their problem in teaching practice and the school problem in implementation 2013 curriculum. Additionally, the discussions provided the opportunity to adjust questions, explore interesting responses which emerged and clarify meaning [9].

\section{RESULTS}

This section will discuss some of the problems that arose when implementing the 2013 curriculum at Primary School Kauman 1 Malang. The first condition when getting to know the 2013 curriculum as a new curriculum replacing the KTSP, shocked and difficult to adapt was the first response from teachers, students and parents of students. This is because there are very significant differences between the two curricula. The difference in assessment, the first problem, is immediately felt by the teachers and also the students' parents. In the KTSP curriculum, there is $60 \%$ the form of academic assessment while $40 \%$ for skills assessment.

All the assessments in KTSP are represented by numbers as a result of students' learning progress. Whereas in the 2013 curriculum, the academic assessment was $40 \%$ and $60 \%$ skills assessment. Moreover, the grades were represented no longer by numbers but by descriptions in each subject. This fact has aroused some controversy among the parents of students. The students' parents feel less satisfied just by accepting the results of their children's learning achievements in the form of description only. Besides the parents, the teachers also felt difficulties with the assessment system. Therefore, to overcome this problem the assessment form has been revised so for now the form of assessment is in the form of numbers and descriptions from the students learning outcomes. Furthermore, this form is more acceptable to the guardians of students.

The second problem is the teacher's book and student's book. To overcome this problem, the teachers conducted workshops in Blitar and Batu in the context of joint book review. If these books are deemed insufficient then they will be added. Therefore, there are teachers books of elementary school Kauman 1 that have been revised. The revision began from 2013 to 2016 and for 2017 and 2018 the books were the same without any revision.

Delivering lesson of each subjects is the third problem faced by teachers and also students at Primary School Kauman 1 by using the 2013 curriculum. In the 2013 curriculum, the subjects were in the form of integrated thematic in which all subjects were merged into one. It means while explaining about Indonesian language lessons there were also singing lessons and civic. Using KTSP, on the other hand, the process of delivering subjects is easier because each subject stands alone so students also do not feel confused. To overcome this problem, it definitely takes a long time to get used to it. Therefore, in its application, the 2013 curriculum at Primary School Kauman 1 Malang is implemented in stages as shown in the following Table 1.

Based on the various problems above, currently Primary School Kauman 1 Malang has been able to implement the 2013 curriculum simultaneously in all grade levels and its implementation has been $100 \%$ integrated in accordance with the provisions of the 2013 curriculum

Table 1

2013 Curriculum Implementation Process

\begin{tabular}{|l|l|}
\hline \multicolumn{1}{|c|}{ Year } & \multicolumn{1}{c|}{ Class implemented } \\
\hline $2013-2014$ & Grade 1 and 4 \\
\hline $2014-2015$ & Grade 2 and 5 \\
\hline $2015-2016$ & Grade 3 and 6 \\
\hline 2017 and so on & All grades \\
\hline
\end{tabular}

\section{DISCUSSION}

In this implementation section, it will be discussed the differences in the implementation of KTSP and the 2013 curriculum. In its application, the subject matter in KTSP is chosen based on the learning objectives or competencies to be achieved. So that in this curriculum the learning process focuses on one subject with some basic competencies. For the breadth and depth of the material will be adjusted to the characteristics of students (including fast and slow, highly motivated or low motivated) [10]. With this kind learning process, the delivery of one material can be done repeatedly (not enough completed in one meeting). It will be done until all the students can achieve the desired competencies. Whereas in 2013 curriculum, the learning is in the form of thematic learning namely learning that uses themes in linking several subjects so as to provide meaningful experiences to students [10].

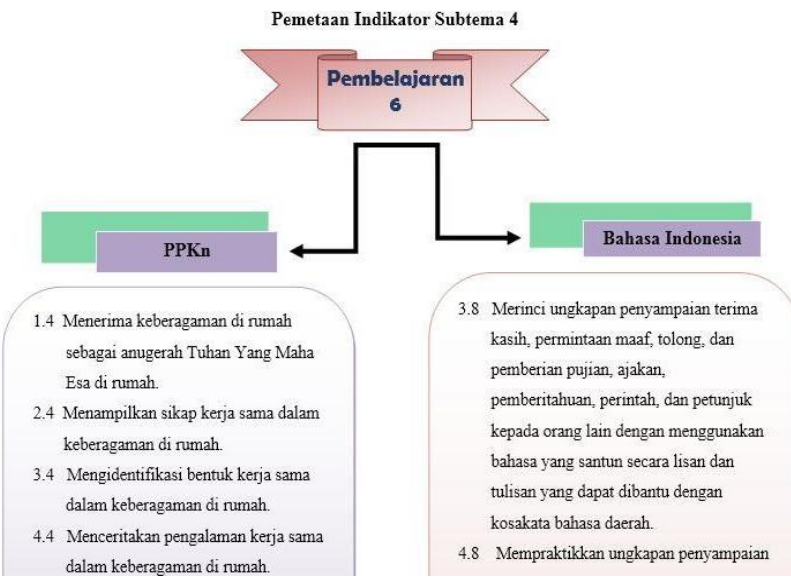

Figure 1

Example of Theme SD Grade 1

In this learning process, one theme requires one meeting and will not be repeated because the time allocation available is set in the 2013 curriculum rules (Figure 1). Furthermore, for learning outcomes in K-13, the learning outcomes are in accordance with the potential of each student. Next the assessment system in KTSP depends on the type of competency and indicators of learning outcomes to be achieved, the type of learning material and the purpose of the assessment itself. In line with [10] the diversity of assessments in KTSP is illustrated by the existence of several tests conducted by teachers to measure students' abilities, for example, holding pre-tests and post-tests.

Then the results of the assessment tend to judge only the academic aspects. As for the evaluation on K-13, 
academic ability has a portion of $40 \%$. Because the 2013 curriculum focuses on the assessment of skills with a percentage of $60 \%$ with aspects of assessment which include KI 1 (spiritual), KI 2 (social), KI 3 (knowledge) and KI 4 (attitude). The shift from test assessment (KTSP) to authentic assessment (measuring all attitude competencies, skills, and knowledge based on process and results) that characterizes the 2013 curriculum like the example below which is an attitude observation sheet used by teachers during the teaching learning process (Figure 2).

LEMBAR PENGAMATAN DAN PENSKORAN KINERJA SISWA

a. Lembar Pengamatan Penilaian Sikap

\begin{tabular}{|c|c|c|c|c|c|c|c|c|c|c|c|c|c|}
\hline \multirow{4}{*}{ No } & \multirow{4}{*}{ Nama Peserta Didik } & \multicolumn{12}{|c|}{ Sikap } \\
\hline & & \multicolumn{8}{|c|}{ KI-2 Sikap Sosial } & \multirow{2}{*}{\multicolumn{4}{|c|}{$\begin{array}{c}\text { KI-1 Sikap Spiritual } \\
\text { Religius }\end{array}$}} \\
\hline & & \multicolumn{4}{|c|}{ Percaya Diri } & \multicolumn{4}{|c|}{ Kerja Sama } & & & & \\
\hline & & 1 & 2 & 3 & 4 & 1 & 2 & 3 & 4 & 1 & 2 & 3 & 4 \\
\hline 1. & ACHMAD R.H. & & & & & & & & & & & & \\
\hline 2. & ADHYASTHA EKA N. & & & & & & & & & & & & \\
\hline 3. & AEZAR MIFTAHUL $\mathrm{H}$. & & & & & & & & & & & & \\
\hline 4. & AGHA ADELIA ZAHRA & & & & & & & & & & & & \\
\hline 5. & AISYAH AFIQAH & & & & & & & & & & & & \\
\hline 6. & AL FATIH SADIRLANZAH & & & & & & & & & & & & \\
\hline 7. & ANQI FIDYAN ZAKIYAL F & & & & & & & & & & & & \\
\hline 8. & ARIF ALI ZAKARIA & & & & & & & & & & & & \\
\hline 9. & ARISTO REZKY P. & & & & & & & & & & & & \\
\hline 10. & ARZENOBIA RAJENDRA I. & & & & & & & & & & & & \\
\hline 11. & AZKAYRA RAMADHINA P & & & & & & & & & & & & \\
\hline 12. & DAMAR GANTARI BHUMI & & & & & & & & & & & & \\
\hline 13. & MOHAMMAD HAIDAR A. & & & & & & & & & & & & \\
\hline 14. & MUHAMMAD ARKAN A.C & & & & & & & & & & & & \\
\hline 15. & NABILA AUREL PUTRI A. & & & & & & & & & & & & \\
\hline
\end{tabular}

Figure 2

Student Attitude Observation Sheet

The sheet is filled in by giving a check in accordance with the assessment provisions as follows: score 4 , if all indicators appear in learning activities; score 3 , if there are 3 indicators that appear in the learning activities; score 2, if there are 2 indicators that appear in the learning activities; and score 1 , if there is 1 indicator that appears in the learning activities. Of course, the assessment must refer to existing indicators as written below (Table 2). So that the results obtained will no longer be numbers but letters as in the table below (Table $3)$.
Representations of qualitative values in the form of letters need to be explained in the form of numbers to make it easier to explain to students' parents. Besides attitude assessment there is also a more detailed assessment of knowledge and skills assessment as the table below (Table 4 ).

Table 2

Assessment Indicators

\begin{tabular}{|c|c|}
\hline $\begin{array}{c}\text { Assessment } \\
\text { Aspects }\end{array}$ & Indicator \\
\hline Confidence & $\begin{array}{l}\text { 1. Answering questions from the teacher in a loud } \\
\text { and loud voice } \\
\text { 2. Read the results of the work in front of the class } \\
\text { without hesitation } \\
\text { 3. Do not see a friend's work while doing an } \\
\text { assignment. } \\
\text { 4. Not many do graffiti when completing sheet } \\
\text { work }\end{array}$ \\
\hline Cooperation & $\begin{array}{l}\text { 1. Share tasks when carrying out group discussions } \\
\text { 2. Help friends in groups who are having } \\
\text { difficulties } \\
\text { 3. Not being selfish and not wanting to win alone } \\
\text { in completing group assignments } \\
\text { 4. Don't make noise while working on group } \\
\text { assignments }\end{array}$ \\
\hline Religious & $\begin{array}{l}\text { 1. Want to pray before and after learning } \\
\text { 2. Giving greetings before and after learning } \\
\text { 3. Willing to accept diversity at home by } \\
\text { collaborating. } \\
\text { 4. Give thanks to God Almighty for diversity at } \\
\text { home }\end{array}$ \\
\hline
\end{tabular}

Table 3

Conversion Value

\begin{tabular}{|c|c|c|}
\hline $\begin{array}{c}\text { Qualitative } \\
\text { Assessment }\end{array}$ & $\begin{array}{c}\text { Quantitative } \\
\text { Assessment }\end{array}$ & Description \\
\hline $\mathrm{A}$ & $76-100$ & Good \\
\hline $\mathrm{B}$ & $51-75$ & Fair \\
\hline $\mathrm{C}$ & $26-50$ & Less \\
\hline $\mathrm{D}$ & $1-25$ & Very Less \\
\hline
\end{tabular}

According to the previous information, it has been explained the following problems and solutions related to the 2013 curriculum and its comparison with the previous curriculum, in this case the KTSP was intended. In the next chapter conclusions and suggestions will be given.

Table 4

Skill Assessment Indicator

\begin{tabular}{|l|l|l|l|l|}
\hline \multicolumn{1}{|c|}{ Aspects } & \multicolumn{1}{c|}{ Very Good (4) } & \multicolumn{1}{c|}{ Good (3) } & \multicolumn{1}{c|}{ Adequate (2) } \\
\hline $\begin{array}{l}\text { Pancasila and civic } \\
\text { education }\end{array}$ & $\begin{array}{l}\text { The story is written in } \\
\text { accordance with the } \\
\text { selected picture, write the } \\
\text { title of the story, the story } \\
\text { contains 5 sentences or } \\
\text { more, the writing is neat, } \\
\text { clear, and easy to read. }\end{array}$ & $\begin{array}{l}\text { The story is written in } \\
\text { accordance with the } \\
\text { selected picture, write the } \\
\text { title of the story, the story } \\
\text { consists of 4 sentences, } \\
\text { neatly written, clear, and } \\
\text { easy to read. }\end{array}$ & $\begin{array}{l}\text { The story is written in } \\
\text { accordance with the } \\
\text { selected picture, write the } \\
\text { title of the story, the story } \\
\text { is written only consists of } \\
3 \text { sentences, neatly written, } \\
\text { clear, and easy to read. }\end{array}$ \\
$\begin{array}{l}\text { Indonesian Language } \\
\text { selected picture, write the } \\
\text { title of the story, the story } \\
\text { sentences, the writing is } \\
\text { not neat and difficult to } \\
\text { read. }\end{array}$ & $\begin{array}{l}\text { Arrange 5 sentences of } \\
\text { requests for help correctly, } \\
\text { neat writing, easy to read, } \\
\text { and proportional pauses. }\end{array}$ & $\begin{array}{l}\text { Arrange 4 sentence } \\
\text { requests for help with } \\
\text { proper, neat writing, easy } \\
\text { to read, and proportional } \\
\text { pauses. }\end{array}$ & $\begin{array}{l}\text { Arrange 3 sentence } \\
\text { requests for help correctly, } \\
\text { writing rather neat, easy to } \\
\text { read, and proportional } \\
\text { pauses. }\end{array}$ \\
$\begin{array}{l}\text { sentences of requests for } \\
\text { help correctly, the text is } \\
\text { not neat, easy to read, and } \\
\text { the gap is less } \\
\text { proportional. }\end{array}$
\end{tabular}

\section{CONCLUSION}

The difference between the previous curriculum (KTSP) and the 2013 curriculum is very noticeable and the difference was apparent. If summarized in a number of important points that characterize the 2013 curriculum namely graduate competencies which include aspects of competency attitudes, skills, and knowledge. Furthermore, there is a reduction in the number of 
subjects at the elementary level, which are originally stand-alone subjects now becoming thematic. In addition, the learning process is no longer centered on the teacher but on students, students are required to be more actively ask questions, reason, process and conclude themselves and finally the assessment process is more authentic.

The existence of curriculum changes that occur is part of the demands of the changing times so that adjustments need to be made. It is hoped that with this 2013 curriculum students can have not only mastery of knowledge but also good skills. So that the system in the 2013 curriculum is indeed focused on skills at a lower level and knowledge for higher levels.

\section{REFERENCES}

[1] Sonhadji, A. 2018. Manusia, Teknologi, dan Pendidikan Menuju Peradaban Baru. Malang: Universitas Negeri Malang.
[2] Oemar, H. 2009. Dasar-dasar Pengembangan Kurikulum. Bandung: PT Remaja Rosdakarya.

[3] Hidayat, S. 2013. Pengembangan Kurikulum Baru. Bandung: PT Remaja Rosdakarya.

[4] Salinan Lampiran Permendikbud No. 59 Tahun 2014 Kurikulum 2013 Sekolah Menengah Atas/Madrasah Aliyah, Rom I, Point (A). Jakarta: Kemdikbud.

[5] E. Mulyasa. 2013. Pengembangan dan Implementasi Kurikulum 2013. Bandung: PT Remaja Rosdakarya.

[6] Syafruddin, N. 2003. Guru Profesional dan Implementasi Kurikulum. Jakarta: Ciputat Press.

[7] Riyanto, O. 2012. Research Methodology. Bandung: SIC.

[8] Tohirin. 2012. Metode Penelitian Kualitatif dalam Pendidikan dan Bimbingan Konseling. Jakarta: PT Raja Grafindo Persada.

[9] Robson, C. 2011. Real World Research. Chichester: John Wiley and Sons.

[10] Muslich, M. 2009. KTSP Pembelajaran Berbasis Kompetensi dan Kontekstual. Jakarta: PT Bumi Aksara. 